\title{
MIR516B2 wt Allele
}

National Cancer Institute

\section{Source}

National Cancer Institute. MIR516B2 wt Allele. NCI Thesaurus. Code C82494.

The human MIR516B2 wild-type allele is located in the vicinity of 19q13.41 and is approximately 84 bases in length. This allele, which encodes MIR516B2 pre-miRNA, plays a role in the regulation of gene expression. Alteration in the expression of this gene is associated with development of breast cancer. 